\title{
Knowledge, attitude and preventive practices related to novel Coronavirus Infection (COVID-19) among patients attending dental hospital in Dharwad
}

\author{
Hema Tyavanige Shekarappa ${ }^{1}$, Kruthika Satyabodh Guttal ${ }^{2}$, Varuni lyer ${ }^{3}$, Vani Gupta ${ }^{4}$, \\ Preeta Shetty ${ }^{5}$
}

${ }^{1}$ Assistant Professor, ${ }^{3,4}$ Interns ${ }^{5}$ Professor Department of Public Health Dentistry, ${ }^{2}$ Professor Department of Oral Medicine \& Radiology, SDM College of Dental Sciences and Hospital Shri Dharmasthala Manjunatheshwara University, Dharwad India

\section{A B S T R A C T}

Background: The Novel Coronavirus Disease 19 (COVID-19) is one of the deadly diseases declared as pandemic by WHO. The managing strategies include prevention of spread of the infection and awareness regarding the preventive practices, which are very vital in preventing the exponential spread of the disease. Despite the rolling commentary over telephone calls and advertisements at every desk, public is too negligent over this global threat. Aims and Objectives: The present questionnaire based study was aimed to assess the knowledge, attitude and preventive practices existing among the public to face the pandemic. Materials and Methods: The present study was a cross-sectional questionnaire based study using a convenience sampling method. The patients attending the outpatient section of the Oral Medicine department of a Dental Hospital for various dental complaints were interviewed by telephonic conversation. Patient's knowledge and awareness regarding the prevailing situation created by the media was assessed. Results: Seventy-seven point seven percent of the participants were following the preventive practices. They had an average attitude towards the prevention of spread of infection (52.4\%) and considering COVID-19 as a serious infection $(51.8 \%)$. Younger population, professionals and females had an overall better Knowledge, Attitude and Practices. Conclusions: Majority of the assessed population had a sound knowledge about the pandemic. Certain key issues like visiting the hospitals only for emergencies needs to be emphasised by health care professionals to prevent the spread of the disease.

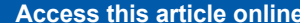

Website:

http://nepjol.info/index.php/AJMS DOI: 10.3126/ajms.v11i5.29857

E-ISSN: 2091-0576

P-ISSN: 2467-9100

Copyright (c) 2020 Asian Journal of Medical Sciences

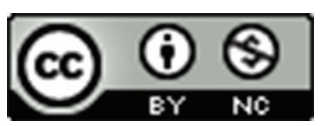

This work is licensed under a Creative Commons Attribution-NonCommercial 4.0 International License.

Key words: KAP; Pandemic; Preventive practices; COVID-19

\section{INTRODUCTION}

The novel Coronavirus Disease 19 (COVID-19) outbreak has currently become one of the major concerns across the globe. With the first case in Wuhan, Hubei district, China on 31 December 2019 was reported as pneumonia of an unknown cause and it has been spreading fast. ${ }^{1}$ Since January 2020, cases had been reported outside China as the individuals began to travel to various other countries. ${ }^{1}$ WHO announced COVID-19 as a Public Health Emergency of International Concern on 30th January
2020. ${ }^{1}$ The world is not new to such an emergency as the history did report Severe Acute Respiratory syndrome (SARS) in 2002 and Middle Eastern Respiratory Syndrome (MERS) in 2012. But the scale at which the COVID-19 is being reported across different nations not only instils sense of panic but also agitates various sectors as dealing with the prevention and cure of this pandemic serves as a major challenge.

COVID-19, like SARS-CoV and Middle East Respiratory Syndrome Coronavirus (MERS-CoV), belongs to 
Coronavirus family, ${ }^{2}$ which is a zoonotic virus that manifests Pneumonia-like symptoms. ${ }^{2}$ It is transmitted through air-droplets among humans when the infected person coughs or sneeze. ${ }^{3}$ The most common symptoms of COVID-19 are fever, tiredness and dry cough with an incubation period from 1 to 14 days. ${ }^{3}$ Some patients may have aches and pains, nasal congestion, running nose, sore throat or diarrhea. ${ }^{3}$ These symptoms are usually mild and begin gradually. Testing for COVID-19 includes molecular recognition and serology testing. ${ }^{4}$ The sample source for the tests include swabs from nasopharyngeal region or even sputum sample. ${ }^{4}$ Results are generally available within a few hours to 2 days. ${ }^{5}$ Currently, there are no specific vaccines or treatments for COVID-19. However, there are many ongoing clinical trials evaluating potential treatments.

People of all ages can be infected by the novel coronavirus COVID-19. Older people, and people with pre-existing medical conditions (such as asthma, diabetes, heart disease) appear to be more vulnerable to becoming severely ill with the virus. ${ }^{1}$ COVID-19 virus can be transmitted in areas with hot and humid climates. Cold weather and snow cannot kill the new coronavirus. ${ }^{1}$

Various measures have been taken by the Government and other health services to prevent the further spread. Health care professionals are at highest risk to contract the disease either from affected people or from asymptomatic secondary contacts. Personal protective equipments, hand sanitization, cleanliness of the surroundings, social distancing, self-isolation is the need of the hour and form the most crucial aspects of preventive strategies advocated. ${ }^{6}$ In order to battle this global threat, every individual is ought to follow the stringent measures towards preventing the COVID-19 spread and serve to help recover the ones affected.

As of 7 th July, there were around 259557 active cases of COVID-19 in India. ${ }^{7}$ This rise in number could be attributed to varied reasons, one of which is the lack of awareness and appropriate attitude among the public towards this outbreak. Despite the rolling commentary over telephone calls and advertisements at every desk, public is too negligent over this global threat.

Knowledge attitude \& preventive practices (KAP) studies aid in identifying what is known and what needs to be done about various health-related challenges. In addition, KAP studies will assist in suggesting an intervention strategy and plan activities that are suited to the respective population involved. In view of emerging global pandemic of novel COVID-19 infection and its crisis, the present questionnaire based study was designed with an objective to assess the Knowledge, Attitude \& Preventive Practices (KAP) among the public regarding the existing awareness of the new pandemic, necessary precautions advised and practiced for preventing the spread of COVID-19 pandemic disease. Since KAP studies have advantage of action tool embedded, they will contribute not only assessment of the awareness existing in the public but also to utilise the data to educate the public about the rising pandemic.

\section{MATERIALS AND METHOD}

Study design and sampling - A cross sectional survey was carried out among the patients who visited the outpatient section of the Oral Medicine department of a Dental hospital for a period of 15 days from 08/03/2020 to 22/03/2020 through telephonic interview.

Sample Size determination - A pilot study was conducted among twenty patients to assess the required sample size for the study. The final sample size was estimated to be 723 with the Confidence level of 95\%, which was deduced with the formula. ${ }^{8}$

$\mathrm{n}=\mathrm{Z}_{(1-\alpha / 2)}^{2} \mathrm{p}(1-\mathrm{p})$

where, $\mathrm{p}:$ Expected Proportion, $\varepsilon$ : Relative precision $\varepsilon \mathrm{p}^{2}(1-\alpha / 2)$ : Desired Confidence level.

Questionnaire: For the purpose of the study, the questionnaire was developed to assess the knowledge, attitude and preventive practices related to Novel COVID-19. The questionnaire (Appendix-1) contained, data regarding the demographic profile of the patients, 7 items enquiring the Knowledge, 5 items related to the attitude and 3 questions pertaining to the preventive practices related to COVID 19. The questionnaire was given to the subject experts to assess the content validity. The questionnaire was finalised after revision and modification of the original version. The questionnaire was framed in English language which was translated to the local language Kannada by a language professional, later the questionnaire was back translated to English to ensure the validity. Questionnaire was read out both in English and local language Kannada.

Two researches were trained to conduct the telephonic interview of the patients, as it was not advisable to have any type of contact with the patients during the COVID 19 outbreak. As majority of the people speak regional language Kannada and English in this region, interviewers fluent in these languages were selected to conduct the telephonic interview. Interviewer's bias was addressed by training the 
interviewers to read out each question exactly as it appears on the questionnaire and were asked not to interpret the questions for the interviewee.

Data Collection: Data was collected using a convenience sampling. The telephonic interview was preceded with the patients who visited the dental hospital between 08/03/2020 to 22/03/2020 for various dental complaints and those who were willing to participate and consented to be a part of the study. Patients unwilling to participate in the study and the ones having suffered road traffic accidents and with acute dental emergencies and those who were unable to comprehend to questionnaire were excluded from the study. The average time taken for each telephonic interview was about 8-10 minutes. On an average each day 48-50 patients were interviewed by both the interviewers. Ethical clearance for conducting the survey was obtained from the institutional review board.

Statistical Analysis: Statistical Package for the Social Sciences Version 20 was used for statistical analysis. Descriptive Statistics including Kruskal wallis test, MannWhitney $U$ tests were performed. The level of significance was set at $\mathrm{p} \leq 0.05$.

\section{RESULTS}

A total of 723 participants completed the telephonic interview, amongst which 363 were males and 360 were females. The average age of the participants was 38.93 years. Majority of the participants belonged to the age group of 20 to 50 . Occupation wise, most of the participants were unemployed, majority of them being the housewives. In addition to demographic details like age, gender, occupation the travel history of subjects was also recorded. (Table-1).

With respect to COVID-19, 66.4\% participants had better knowledge, as compared their attitude (54.1\%) and preventive practices $(53.8 \%) .83 .7 \%$ of the participants had better knowledge regarding what is corona virus infection, its spread $(77.6 \%)$, the age group it affects $(65.4 \%)$, whether travelling is advisable during the outbreak unless necessary $(58.6 \%)$, number of days a person has to be quarantined $(60.2 \%)$ and the symptoms of the disease $(75.6 \%)$. But very less number of participants knew about what is quarantine $(43.6 \%)$. (Table- 2$)$.

The participants expressed better attitude towards the actions taken by the government to prevent the spread of COVID-19 (77.7\%). They had an average attitude towards the prevention of spread of infection (52.4\%) and considering COVID-19 as a serious infection (51.8\%).

\begin{tabular}{llcc}
$\begin{array}{l}\text { Table 1: Demographic characteristics of the } \\
\text { participants }\end{array}$ & \multicolumn{2}{l}{$\begin{array}{l}\text { Number of } \\
\text { participants }\end{array}$} & Percentage \\
\hline Characteristics & 363 & 50.20 \\
Gender & Male & 360 & 49.79 \\
Age & Female & 64 & 8.85 \\
& $10-19$ & 196 & 27.10 \\
& $20-29$ & 147 & 20.33 \\
& $30-39$ & 127 & 17.56 \\
& $40-49$ & 86 & 11.89 \\
Occupation & $50-59$ & 58 & 8.02 \\
& $60-69$ & 45 & 6.22 \\
& $70+$ & 360 & 49.79 \\
& Unemployed & 73 & 10.09 \\
& Unskilled worker & 174 & 24.06 \\
& Semiskilled worker & 35 & 4.84 \\
& Skilled worker & 66 & 9.12 \\
& Clerical/Shop & & \\
& owner/Farm & 5 & 0.7 \\
& Semiprofessional & 10 & 1.3 \\
& Professional & 4 & 0.55 \\
Travel history & Self & 4 & 0.55 \\
& Family Members & & \\
\hline
\end{tabular}

\begin{tabular}{|c|c|c|}
\hline & Question number & Percentage \\
\hline \multirow[t]{8}{*}{ Knowledge } & Do you know about corona virus infection & 83.7 \\
\hline & Do you know how it spreads? & 77.6 \\
\hline & $\begin{array}{l}\text { Do you know which age groups are } \\
\text { more prone to corona virus infection? }\end{array}$ & 65.4 \\
\hline & $\begin{array}{l}\text { Is it advisable to travel anywhere } \\
\text { unless it is an emergency? }\end{array}$ & 58.6 \\
\hline & Do you know what quarantine is? & 43.6 \\
\hline & $\begin{array}{l}\text { Do you how many days a patient } \\
\text { should be quarantined for once he is } \\
\text { tested positive for COV or has been } \\
\text { with a person who was tested positive? }\end{array}$ & 60.2 \\
\hline & $\begin{array}{l}\text { Which do you think are the symptoms } \\
\text { of Corona virus infection? }\end{array}$ & 75.6 \\
\hline & Overall & 66.4 \\
\hline \multirow[t]{6}{*}{ Attitude } & $\begin{array}{l}\text { Do you think the spread of infection } \\
\text { can be prevented? }\end{array}$ & 52.4 \\
\hline & $\begin{array}{l}\text { Do you think it is necessary to avoid } \\
\text { going to dental hospital/clinic unless } \\
\text { there is an emergency? }\end{array}$ & 43.2 \\
\hline & $\begin{array}{l}\text { Do you feel quarantine will help } \\
\text { prevent the spread of infection? }\end{array}$ & 45.3 \\
\hline & $\begin{array}{l}\text { Do you think COVID is a serious } \\
\text { infection? }\end{array}$ & 51.8 \\
\hline & $\begin{array}{l}\text { Do you approve the government } \\
\text { actions taken to prevent COVID like } \\
\text { avoiding gatherings, unnecessary } \\
\text { travelling, and closure of schools and } \\
\text { malls, restaurants, cinema theatres? }\end{array}$ & 77.7 \\
\hline & Overall & 54.1 \\
\hline \multirow[t]{4}{*}{ Practice } & $\begin{array}{l}\text { For what treatment have you come to } \\
\text { the dental hospital? }\end{array}$ & 6.1 \\
\hline & $\begin{array}{l}\text { Which one of the following preventive } \\
\text { measures are you following? }\end{array}$ & 77.7 \\
\hline & $\begin{array}{l}\text { Are you following the government } \\
\text { rules regarding quarantine measures } \\
\text { (avoiding to going to places having more } \\
\text { than } 10 \text { people unless emergency)? }\end{array}$ & 77.7 \\
\hline & Overall & 53.8 \\
\hline
\end{tabular}


The participants had lower attitude score for questions like, is it necessary to avoid going to hospital/clinic unless emergency (43.2\%) and if the quarantine will help prevent the spread of infection (45.3\%).

Related to preventive practices, majority of the participants had visited the dental hospital for non-emergency treatments. Only $6.1 \%$ of the participants visited the dental hospital for availing emergency treatments. Majority $(77.7 \%)$ of the participants were following the preventive procedures as well as the government rules related to the social distancing measures. (Table-2)

Kruskal Wallis ANOVA test for the comparison of Knowledge, attitude and practices between the age groups showed a statistically significant difference between the age groups ( $\mathrm{p}=0.001, \mathrm{p}=0.001, \mathrm{p}=0.008$ respectively). The participants belonging to 20-29 year had the maximum knowledge (32.4) followed by 30-39 age groups (23.03). The least knowledge scores were seen among the older age participants 60-69 and 70+ age groups with scores of 4.5 and 2.5 respectively. The same pattern followed with respect to attitude wherein 20-29 age group people had higher scores for attitude (38.2) and least scores were seen among 60-69 year (2.8) and 70+ years (1.7). The preventive practices were better followed among 30-39 years old (32.1) and poor preventive practices were seen among 70 and above old people (1.6) (Table-3)

Mann Whitney U Test was used to test the percentage of correct answers with respect to Knowledge, Attitude and Practices by gender. There was a statistically significant difference between the gender with respect to Knowledge, Attitude and Practices $(\mathrm{p}=0.011, \mathrm{P}=0.009, \mathrm{p}=0.029$ respectively). Females had an overall better Knowledge,
Attitude and practices regarding Covid-19 compared to males. (Table 4)

When the percentage of correct responses according to different professions with respect to knowledge, attitude and preventive practices was compared, it was evident that the overall knowledge level was better among all the occupations compared to their attitude and practices related to COVID-19. It was observed that the highest knowledge and attitude scores were seen amongst the professionals and least knowledge and attitude scores were seen amongst the unskilled workers. With respect to the preventive practices, better scores were observed among the semi-professionals followed by professionals and least scores were seen among the unskilled workers. (Table-5).

\section{DISCUSSION}

COVID-19 disease is one of the worse known pandemics of this century. It is crucial to encourage the public to adopt precautionary measures, based on the appropriate knowledge of the epidemic and response from the general public, as strict compliance to preventive measures advocated by the government authorities plays a key role to prevent the community spread of the disease. As the details of this emerging disease is not completely clear to the health professionals, knowledge, attitude regarding adoption of preventive measures like maintaining social distancing and regular hand sanitization is a responsibility from the general population as well to prevent the growing number of cases.

To the best of our knowledge, this is the first study in India assessing the KAP towards COVID-19 among patients

\begin{tabular}{|c|c|c|c|c|c|c|c|c|c|}
\hline & \multirow{2}{*}{$\begin{array}{l}\text { Question } \\
\text { number }\end{array}$} & \multicolumn{7}{|c|}{ Age-Group } & \multirow[t]{2}{*}{ P Value } \\
\hline & & $10-19$ & $20-29$ & $30-39$ & $40-49$ & $50-59$ & $60-69$ & $70+$ & \\
\hline \multirow[t]{8}{*}{ Knowledge } & Q1 & 10.1 & 31.8 & 23.3 & 19 & 9.9 & 4.1 & 1.7 & \\
\hline & Q2 & 10.5 & 33 & 24.8 & 19.6 & 7.7 & 3.4 & 0.9 & $0.001^{*}$ \\
\hline & Q3 & 11.7 & 35.2 & 24.6 & 17.8 & 7 & 2.8 & 1.1 & \\
\hline & Q8 & 5.4 & 17.7 & 20.8 & 18.9 & 15.8 & 12.1 & 9.2 & \\
\hline & Q9 & 14.6 & 40.3 & 21.9 & 13.7 & 5.1 & 2.9 & 1.6 & \\
\hline & Q11 & 11 & 35.4 & 24.4 & 17.9 & 6.9 & 3 & 1.4 & \\
\hline & Q13 & 10.3 & 33.7 & 23.4 & 19.4 & 8.4 & 3.5 & 1.3 & \\
\hline & Overall & 10.5 & 32.4 & 23.3 & 18.0 & 8.7 & 4.5 & 2.5 & \\
\hline \multirow[t]{6}{*}{ Attitude } & Q4 & 12.2 & 39.7 & 23 & 14.8 & 5.6 & 3.2 & 1.6 & $0.001^{*}$ \\
\hline & Q7 & 13.8 & 39.7 & 20.8 & 16 & 5.4 & 2.2 & 1.9 & \\
\hline & Q10 & 15.3 & 40.7 & 22 & 12.8 & 4.3 & 3.4 & 1.5 & \\
\hline & Q12 & 13.6 & 37.7 & 23 & 15.8 & 5.6 & 2.4 & 1.9 & \\
\hline & Q14 & 10.5 & 33.3 & 23.7 & 19.3 & 8.9 & 2.9 & 1.4 & \\
\hline & Overall & 13.1 & 38.2 & 22.5 & 15.7 & 6.0 & 2.8 & 1.7 & \\
\hline \multirow[t]{4}{*}{ Practice } & Q5 & 4.5 & 29.5 & 36.4 & 6.8 & 11.4 & 9.1 & 2.3 & \\
\hline & Q6 & 9.8 & 33.2 & 23.2 & 18.9 & 9.3 & 4.5 & 1.2 & $0.008^{*}$ \\
\hline & Q15 & 10.5 & 33.7 & 23.2 & 19.1 & 8.9 & 3.4 & 1.2 & \\
\hline & Overall & 8.3 & 32.1 & 27.6 & 14.9 & 9.9 & 5.7 & 1.6 & \\
\hline
\end{tabular}


and general public. It was evident in the present survey that the participants had better knowledge, as compared to their attitude and preventive practices which is similar to results of study by Olum $\mathrm{R}$ et al. ${ }^{9}$ This leads us to emphasise the importance of preventive practices and educating the masses of the importance of prevention in limiting the community spread. Related to preventive practices, majority of the participants had visited the dental hospital for non-emergency treatments, which again as health professionals we need to educate the public regarding postponing of non-emergency treatment, as it is evident that aerosol related treatments are known to increase the spread of COVID-19. ${ }^{10}$ Zhou W et al, in their study have proposed that besides improving the

\begin{tabular}{|c|c|c|c|c|}
\hline & \multirow{2}{*}{$\begin{array}{l}\text { Question } \\
\text { number }\end{array}$} & \multicolumn{2}{|c|}{ Sex } & \multirow[t]{2}{*}{ P Value } \\
\hline & & Male & Female & \\
\hline \multirow[t]{8}{*}{ Knowledge } & Q1 & 49 & 51 & \multirow[t]{8}{*}{$0.011^{*}$} \\
\hline & Q2 & 48 & 52 & \\
\hline & Q3 & 47.5 & 52.5 & \\
\hline & Q8 & 51.1 & 48.9 & \\
\hline & Q9 & 49.8 & 50.2 & \\
\hline & Q11 & 48.3 & 51.7 & \\
\hline & Q13 & 48 & 52 & \\
\hline & Overall & 48.8 & 51.2 & \\
\hline \multirow[t]{6}{*}{ Attitude } & Q4 & 50.8 & 49.2 & \multirow[t]{6}{*}{$0.009^{*}$} \\
\hline & Q7 & 48.1 & 51.9 & \\
\hline & Q10 & 48.3 & 51.7 & \\
\hline & Q12 & 48.9 & 51.1 & \\
\hline & Q14 & 49.2 & 50.8 & \\
\hline & Overall & 49.1 & 50.9 & \\
\hline \multirow[t]{4}{*}{ Practice } & Q5 & 43.2 & 56.8 & \multirow[t]{4}{*}{$0.029^{*}$} \\
\hline & Q6 & 48.8 & 51.2 & \\
\hline & Q15 & 49 & 51 & \\
\hline & Overall & 47 & 53 & \\
\hline
\end{tabular}

medical levels, media can be considered as an elective way to mitigate the disease spreading during the initial stage of an outbreak. ${ }^{11}$ Majority $(77.7 \%)$ of the participants were following the preventive procedures as well as the government guidelines related to the social distancing measures, this highlights the fact that preventive guidelines advocated by government and health authorities by various social media platforms were being adhered to. When knowledge and attitude measures were compared among different age groups, it was apparent that younger age groups had better knowledge and attitude towards the prevailing situation, but the findings are in contrast with the study by Erfani A et $\mathrm{al}^{12}$ and Srichan P et al, ${ }^{13}$ where it was evident that the knowledge was better among older age groups. This finding could be probably be attributed to the extensive use of social media by the younger generation in India. Possibly this can be highlighted, that youth can take a step forward to advice the older generation, having limited access to social platforms, regarding the incoming and changing measures of preventive practices to fight the spread of infection. In contrast, when compared among genders, it was seen that females had an overall better Knowledge, Attitude and practices regarding COVID-19 compared to males which is similar to the studies by Amirhossein Erfani et.al, and Peerdone Srichan et. al. ${ }^{12,13}$ Whereas a study by Olum R et al, ${ }^{9}$ shows that males had better knowledge compared to females. When compared KAP among different professionals, it was observed that the highest knowledge and attitude scores were seen amongst the professionals which is in accordance with a study by Bhagavathula A S et, al, ${ }^{14}$ and least knowledge and attitude scores were seen amongst the unskilled workers $\&$ with respect to the preventive practices, better scores

Table 5: Percentage of correct response based on different occupations

\begin{tabular}{|c|c|c|c|c|c|c|c|c|c|}
\hline & & \multicolumn{7}{|c|}{ Occupation } & \multirow[t]{2}{*}{ Total } \\
\hline & & Unemployed & Unskilled & $\begin{array}{l}\text { semiskilled } \\
\text { worker }\end{array}$ & $\begin{array}{l}\text { Skilled } \\
\text { worker }\end{array}$ & $\begin{array}{c}\text { Clerical/shop } \\
\text { owner/farm }\end{array}$ & $\begin{array}{c}\text { Semi } \\
\text { professional }\end{array}$ & Professional & \\
\hline \multirow[t]{8}{*}{ Knowledge } & Q1 & 87.8 & 45.2 & 91.4 & 94.3 & 74.2 & 100 & 100 & 83.7 \\
\hline & Q2 & 82.8 & 28.8 & 89.1 & 82.9 & 68.2 & 33.3 & 100 & 77.6 \\
\hline & Q3 & 70.3 & 21.9 & 78.7 & 60.0 & 53.0 & 33.3 & 90 & 65.4 \\
\hline & Q8 & 54.3 & 88.9 & 54.6 & 45.7 & 68.2 & 66.7 & 50 & 58.8 \\
\hline & Q9 & 48.6 & 13.7 & 41.4 & 54.3 & 43.9 & 33.3 & 90 & 43.6 \\
\hline & Q11 & 65.3 & 17.8 & 74.1 & 48.6 & 47.0 & 66.7 & 80 & 60.2 \\
\hline & Q13 & 81.1 & 31.5 & 84.5 & 74.3 & 66.7 & 100 & 100 & 75.6 \\
\hline & Overall & 70.02 & 35.4 & 73.4 & 65.72 & 60.17 & 61.9 & 87.14 & 66.41 \\
\hline \multirow[t]{5}{*}{ Attitude } & Q4 & 55.6 & 16.4 & 51.7 & 68.6 & 62.1 & 33.3 & 100 & 52.4 \\
\hline & Q7 & 46.7 & 13.7 & 48.9 & 60.0 & 33.3 & 33.3 & 50.0 & 43.2 \\
\hline & Q10 & 51.4 & 15.1 & 42.0 & 62.9 & 36.4 & 66.7 & 100 & 45.3 \\
\hline & Q12 & 57.8 & 16.4 & 50.6 & 65.7 & 51.5 & 33.3 & 80 & 51.8 \\
\hline & Q14 & 82.2 & 24.7 & 90.2 & 85.7 & 69.7 & 100 & 100 & 77.7 \\
\hline \multirow[t]{4}{*}{ Practice } & Q5 & 6.9 & 8.2 & 1.1 & 14.3 & 1.5 & 66.7 & 30 & 6.1 \\
\hline & Q6 & 81.4 & 37 & 85.6 & 82.9 & 75.8 & 66.7 & 100 & 77.7 \\
\hline & Q15 & 82.8 & 24.7 & 90.2 & 82.9 & 68.2 & 100 & 100 & 77.7 \\
\hline & Overall & 57.03 & 23.3 & 58.96 & 60.03 & 48.5 & 77.8 & 76.66 & 53.83 \\
\hline
\end{tabular}


were observed among the semi-professionals followed by professionals and least scores were seen among the unskilled workers. This emphasises the fact that when unskilled and semi-professionals turn up to health care centres, it is better to assess their knowledge and educate them regarding the preventive practices to control the spread of disease.

A study conducted in Chinese population (residents Hubei, China) to investigate Chinese residents' KAP towards COVID-19 revealed that Chinese residents of a relatively high socioeconomic status, in particular women, were knowledgeable about COVID-19, and held optimistic attitudes, and had appropriate practices towards COVID-19. ${ }^{15}$

A sound knowledge on preventive practices and their effective use will ensure the control of disease at community level. The present study is a cross-sectional survey to assess the KAP of general public towards COVID-19. This will not only ascertain whether the preventive steps taken up are being effectively followed but also to know if any lacunae are existing in the attitude towards the expected practices.

\section{CONCLUSION}

COVID-19 infection has emerged as a global pandemic, posing challenge to control and manage the disease. Overall majority of the patients were aware of the existing pandemic situation. Certain key areas like avoiding hospital/ clinic visits unless emergency, importance of quarantine needs to be emphasised by health care professionals. The limitation of the present study is that the samples consisted of public who had reported to the dental hospital. Because of lock down restriction ensuing assessment of KAP in rural areas was not possible. These could be vulnerable populations due limited access to Internet and other social media means. Assessment from older adults and rural population at grass-root level is very essential to know if appropriate preventive practices towards COVID-19 are being practiced. In addition to knowledge about the disease process a positive attitude to overcome the challenge will definitely help to combat the disease.

\section{Limitations of the study}

Though the KAP studies are feasible to provide data on prevailing situations, the results have to be cautiously interpreted, as the practice related responses may have tendency to be altered due to social desirability. Also the participant's honesty in responding to the questionnaire is dubious. This may also reflect on the advisable strategy changes.

\section{REFERENCES}

1. Fini MB. Oral saliva and COVID-19. Oral Oncology. 2020;108: https://doi.org/10.1016/j.oraloncology.2020.104821

2. de Wit, E, van Doremalen, N, Falzarano, Det al. SARS and MERS: Recent insights into emerging coronaviruses. Nat Rev Microbiol. 2016;14: 523-534.

https://doi.org/10.1038/nrmicro.2016.81

3. Peng X, Xu X, Li Y, Cheng L, Zhou X and Ren B. Transmission routes of 2019-nCoV and controls in dental practice. International Journal of Oral Science. 2020; $12: 9$.

https://doi.org/10.1038/s41368-020-0075-9

4. Zhai P, Ding Y, Wu X, Long J, Zhong Y and Li Y. The epidemiology, dignosis and treatment of Covid- 19. International Journal of Antimicrobial Agents. 2020;55:

https://doi.org/10.1016/j.ijantimicag.2020.105955

5. Meng L, Hua F and Bian Z. Coronavirus Disease (COVID-19): Emerging and Future Challenges for Dental and Oral Medicine. Journal of Dental Research. 2020;12:

https://doi.org/10.1177/0022034520914246

6. Infection prevention and control during health care when coronavirus disease (COVID-19) is suspected or confirmed. Interim guidance 2020 [cited 29 June] Available from: URL: https://www.who.int/publications/i/item/WHO-2019-nCoVIPC-2020.4.

7. Home page accessed from URL: https://www.mohfw.gov.in.

8. Lemeshow S, Hosmer DW, Klar J and Lwanga S. Adequacy of sample size in health studies. World Health Organization. (1990). https://apps.who.int/iris/bitstream/handle/10665/41607/0471 925179_eng.pdf; sequence $=1$

9. Olum R, Chekwech G, Wekha G, Nassozi DR and Bongomin F. Coronavirus Disease-2019: Knowledge, Attitude, and Practices of Health Care Workers at Makerere University Teaching Hospitals, Uganda: Frontiers in Public Health. 2020; 181(8).

https://doi.org/10.3389/fpubh.2020.00181

10. Ong SW, Tan YK, Chia PY, Lee TH, Ng OT, Wong MS, et al. Air, surface environmental, and personal protective equipment contamination by severe acute respiratory syndrome coronavirus 2 (SARS-CoV-2) from a symptomatic patient. JAMA. 2020; 323(16):1610-1612.

https://doi.org/10.1001/jama.2020.3227

11. Zhou W, Wang A, Xia F, Xiao Y and Tang S. Effects of media reporting on mitigating spread of COVID-19 in the early phase of the outbreak: Mathematical Biosciences and Engineering. 2020; 17(3): 2693-2707.

https://doi.org/10.3934/mbe.2020147

12. Erfani A, Shahriarirad R, Ranjbar K, Mirahmadizadeh $A$ and Moghadami M. Knowledge, Attitude and Practice toward the Novel Coronavirus (COVID-19) Outbreak: A Population-Based Survey in Iran. Bull World Health Organ. 2020; https://doi.org/10.2471/BLT.20.256651

13. Srichan $P$, Apidechkul $T$, Tamornpark $R$, Yeemard $F$, Khunthason S, Kitchanapaiboon S, et al. Knowledge, attitude and preparedness to respond to the 2019 novel coronavirus (COVID-19) among the bordered population of northern Thailand in the early period of the outbreak: a cross-sectional study. SSRN Electronic Journal. 2020; https://doi.org/10.2139/ssrn.3546046

14. Bhagavathula AS, Aldhaleei WA, Rahmani J, Mahabadi MA and Bandari D K. Novel Coronavirus (COVID-19) Knowledge and Perceptions: A Survey of Healthcare Workers. JMIR Public 
Health Surveill. 2020; 30; 6(2):e19160.

https://doi.org/10.2196/19160

15. Zhong BL, Luo W, Li HM, Zhang QQ, Liu XG, Li WT, et al. Knowledge, attitudes, and practices towards COVID-19 among
Chinese residents during the rapid rise period of the COVID-19 outbreak: a quick online cross-sectional survey. Int J Biol Sci. 2020; 16(10):1745-1752.

https://doi.org/10.7150/ijbs.45221

\section{Authors Contribution:}

HTS and KSG-Concept and design of the study; HTS, VI and VG- data Collection, interpreted the results, prepared first draft of manuscript and critical revision of the manuscript; HTS- Statistically analyzed and interpreted; KSG- reviewed the literature and manuscript preparation; KSG and HTS- Design of the study, statistically analyzed and interpreted, preparation of manuscript and revision of the manuscript; PS- Concept and coordination of the overall study.

Work attributed to:

Department of Public Health Dentistry SDM College of Dental Sciences \& Hospital Shri Dharmasthala Manjunatheshwara University, Dharwad India 580009.

\section{Orcid ID:}

Dr. Hema Tyavanige Shekarappa - (10 https://orcid.org/0000-0003-2830-552X

Dr. Kruthika Satyabodh Guttal- (i) https://orcid.org/0000-0002-9467-3307

Dr. Varuni lyer- (D https://orcid.org/0000-0002-9467-3307

Dr. Vani Gupta- (1) https://orcid.org/0000-0001-7798-8203

Dr. Preeta Shetty- (i) https://orcid.org/0000-0001-6511-6336

Source of support: None, Conflicts of Interest: None

\section{APPENDIX}

\section{Appendix 1: Questionnaire based study on covid-19}

Gender :

Occupation :

Travel History:

Yours:

Your relatives whom you came in contact with:

\begin{tabular}{l} 
Questions \\
\hline Do you know about the Corona Virus Infection? \\
Do you know how it spreads? \\
Do you know which age groups are more prone to \\
Corona Virus Infection? \\
Do you think the spread of infection can be prevented? \\
For what treatment have you come to the Dental Hospital \\
Which of the following preventive measures are you \\
following
\end{tabular}
hospital/clinic unless there is an emergency?

Is it advisable to travel anywhere unless it is an emergency?

Do you know what Quarantine is?

\section{Emergency}

infection?

Do you know how many days a patient should be quarantined for once he is tested positive for CoViD-19 or has been with a person who was tested positive?

Do you think CoViD-19 is a serious infection?

Which do you think are the symptoms of the Corona

Virus Infection?

Do you approve the Government Actions taken to prevent CoViD-19 like avoiding gatherings, unnecessary travelling, closure of schools and malls, restaurants and cinema theatres?

Are you following the government rules regarding quarantine measure (avoiding going to places having more than 10 people unless emergency)?

Yes No

Yes

Children

Old age

Yes

Washing hands with soap Using Mouthmask

Prevent touching other people Avoid unnecessary travel

Yes

Yes

Yes

Yes

No

No

Middle age

Do not Know

No

Non-Emergency

Using Hand Sanitizer

Closing the mouth while Coughing

Avoid Crowded Places

Avoid touching your nose, eyes, mouth and other parts of the face No

No

No

No

14 days 1 month

7 days Do not know

Yes No

Running nose Sore throat

Cough Fever

Difficulty in breathing in severe cases.

Yes No

Yes

No 